\title{
Cost of groundwater protection: major groundwater basin protection zones in Poland
}

\author{
Ewa Krogulec $^{1}$ (D) Jacek Gurwin ${ }^{2} \cdot$ Mirosław Wąsik $^{2}$
}

Accepted: 15 June 2020 / Published online: 22 February 2021

(c) The Author(s) 2021

\begin{abstract}
This paper describes the complex hydrogeological, legal framework and socioeconomic costs of the groundwater protection in major groundwater basins (MGBs) in Poland in accordance with European directives. The hydrogeological criteria developed in Poland for establishing MGBs and the principles of their protection provide more details to the directives that are in force in Europe, which define the general principles for groundwater protection. The procedure of establishing MGB protection zones is connected with a change in local plans and land development and requires an analysis of the cost-benefit relationship in the sphere of social economy in the sector of public economics. The cost assessment was performed on the basis of data from hydrogeological documentations, and the aggregation of subareas to which the same existing and planned development can be attributed. A legal analysis of bans, orders and restrictions together with the identification of the risk of claims in specific hydrogeological and development conditions was a fundamental issue of research. These costs depend on the acreage and land use of the protected area. The unit costs of MGB protection, calculated per $1 \mathrm{~km}^{2}$ of the protection area, for six sample basins were estimated at $€ 120$ to $€ 208,000 / 2$ years $/ 1 \mathrm{~km}^{2}$. The highest costs are generated by establishing protection in urban areas, while the lowest costs are generated in forest areas.
\end{abstract}

Keywords Major groundwater basin · Groundwater management · Cost of protection · Legal application · Groundwater protection zone $\cdot$ Poland

\section{Introduction}

The current total amount of disposable groundwater resources in Poland (according to the condition as of December 31,2016$)$ is approximately 37 million $\mathrm{m}^{3} /$ day $((\mathrm{https}$ ://www.pgi.gov.pl/en/psh/zadania-psh/8862-groundwater-resources-in-poland.html). Ground water is more useful for supply and less vulnerable to pollution than surface water, and it constitutes about $70 \%$ of the total water consumption in Poland. It was

Ewa Krogulec

ewa.krogulec@uw.edu.pl

1 Faculty of Geology, University of Warsaw, Żwirki i Wigury 93, 02-089 Warsaw, Poland

2 Faculty of Earth Sciences and Environmental Management, University of Wroclaw, Cybulskiego 30, 50-205 Wroclaw, Poland 
estimated the total disposable reserves of groundwater were some 7.35 million $\mathrm{m}^{3} /$ day in major groundwater basins.

Research conducted in Poland since the 1980s, in the field of groundwater protection, has enabled formal, that is, expounded in legal regulations, designation of groundwater reservoirs, according to the rank of MGB. The quantitative and qualitative criteria for distinguishing MGBs and the basic principles for their protection within each protection zone, included in legal regulations, have been developed. The Polish Water Law (Water Act 2017) indicates that protection zones, including groundwater reservoirs, can be established to ensure the appropriate quality of water both for public uses and industrial plants requiring high-quality water, as well as to protect water resources. The works and activities undertaken to designate MGBs in Poland have preceded the activities in the field of groundwater protection in the European Union, regulated by some European Union Directives: Directive 2000/60/EC (Water Framework Directive-WFD), which establishes a framework for European Union activity in the field of water policy, Directive 2006/118/EC (Council Directive 91/676/EEC) on the protection of groundwater against pollution and quality deterioration, and Directive 91/676/EEC concerning the protection of waters against pollution caused by nitrates from agricultural sources. Public goods potentially serve all; that is, they are generally available and are subject to the principle of their use regardless of participation in costs, in this case, the costs of establishing a protected zone (Mechlem 2016). Integrated programs and methodology to designate systems, areas or basins to protect strategic groundwater resources have not been developed in EU. The methods used for MGB protection zone delimitation remain in general compliance with principles developed in other countries, especially considering how vulnerable the basin is to pollution and what is the level of groundwater abstraction. A proposal of methodology for delineating groundwater safeguard zonesDrinking Protected Areas (DWPAs), is given, for example, by Bussard et al. (2006) or Jiménez-Madrid et al. (2016, 2018). As it was presented by Jiménez-Madrid et al. (2018) the restrictions and conditions applied to the activities in the protected zones have direct socioeconomic consequences on the municipalities, and such a concept is quite close to the assumptions made in our research. Delimitation of the boundaries of MGBs and the rules for their protection are an important part of groundwater protection issues. These rules take into account previous experiences and current common legal provisions, and the methodology refers to the principles set out in the "Guidance on Groundwater in Drinking Protected Areas (DWPAs)", which is part of the European Commission's program "Common Implementation Strategy for WFD (2000/60/EC)" (Directive 2006/118/EC). Each country in Europe has regulated the delimitation of protected areas of DWPAs in a different way (Garcıa Garcıa and Martınez Navarrete 2005; Jiménez-Madrid et. al. 2012). In Poland, the types of protected areas include not only protected areas of DWPAs but also reservoir-containing strategic groundwater resources (MGBs). Under WFD, Member States to ensure the necessary protection for groundwater bodies including bodies designated as Drinking Water Protected Areas (DWPAs) may establish protected zones for those bodies of water (Common implementation..., 2007). The MGB protection zones were established depending on hydrogeological condition - the flow time needed for water infiltration from the ground surface to a saturated zone. But protected zones in the field are established by the regional Governor (Voivode), under local regulations. Because of the diversity of circumstances in land development, the procedure of establishing MGB protection zones is connected with a change in local plans and land development, and it requires an analysis of the cost relationship in the sector of public economics. The presented approach to the delineation of 
safeguard zones to give the most effective protection for strategic water resources and to highlight that groundwater protection is particularly important in wide even of economic and social cost.

The Polish Environmental Protection Law (EPL) determines, among others, the rules for paying compensation due to restrictions on the mode of use of real estate in connection with the establishment of groundwater basin protection zones. The State Treasury is obliged either to pay compensation or to purchase the real estate. The establishment of a protection zone of MGBs requires an analysis of the cost-benefit relationship. The cost-benefit analysis captures both quantitative and qualitative elements. Among these, they have economic, social and ecological issues. The key question that the paper aims to answer is related to the cost implications, mainly. All of this work is to show how much costs should be incurred depending on the land cover, existing and planned spatial development, proposed injunctions/prohibitions/ limitations, possible claims, etc. within a particular groundwater basin. The benefits relate to the common resource, that is, to groundwater. In the sphere of social economy in the sector of public economics (Stiglitz 2004), it follows that groundwater is a public good. The existence of public goods can be associated with the category of occurrence of collective needs. The feature of public goods (Samuelson and Nordhaus 1999) is the principle of nonexclusion, that is, the impossibility of excluding individuals from the opportunity to use them. Public goods potentially serve all; that is, they are generally available and are subject to the principle of their use regardless of participation in costs, in this case, the costs of establishing a protected zone (Mechlem 2016). The methods used for MGB protection zone delimitation remain in general compliance with principles developed in other countries, especially considering how vulnerable the basin is to pollution and what is the level of groundwater abstraction. All necessary calculations and analyses were made utilizing the numerical flow models. A proposal for this type of methodology for delineating groundwater safeguard zones is given, for example, by Bussard et al. (2006) or Jiménez-Madrid et al. (2012, 2016). As it was later presented by Jiménez-Madrid et al. (2018), the restrictions and conditions applied to the activities in the study area have direct socioeconomic consequences on the municipalities built on the GWB; that is why they proposed some method of assessing the positive and negative impacts of designations of protected areas, and such a concept is quite close to the assumptions made in our research. The cost estimation was carried out in several stages according to the methodology (Sowińska et al. 2015) formally approved by the Water Management Authority. In the first stage, the protection area was delimited into aggregated spatial units. In the next stage, a legal analysis of bans, orders and restrictions proposed in the hydrogeological documentation was accomplished. The next step was to identify the risk of claims, and the final cost estimation was performed according to these multifaceted criteria. Such estimates for regional hydrogeological structures have not been made so far, nor have they been checked how they will function in practice.

Undoubtedly, the novelty of this research is the ability to compare costs for large regional systems with completely different hydrostructural assumptions and diversified spatial development. This can be a universal premise for this type of research in different countries.

\section{Major groundwater basins in Poland}

The wide range of hydrogeological research carried out in Poland in the period 1986-1989 enabled the development of criteria for distinguishing reservoirs across the whole country, according to the rank of MGB (Kleczkowski 1984). The concept of major groundwater 
basins was based on geological structures of regional and greater extents which are abundant in good-quality groundwater. MGBs are reservoir-containing strategic groundwater resources meeting specific quantitative and qualitative criteria, that is, well-potential discharge rate above $70 \mathrm{~m}^{3} / \mathrm{h}$, intake discharge rate over $10,000 \mathrm{~m}^{3} /$ day and conductivity above $10 \mathrm{~m}^{2} / \mathrm{h}$ (Table 1), where the water is suitable for use in the raw state or after a simple treatment with currently used and economically justified technologies. In deficit zones, individual quantitative criteria have been applied mainly in mountainous areas, much lower than the basic ones (Kleczkowski 1984; Skrzypczyk 2015).

In total, 180 MGBs have been designated (Fig. 1). As part of the documentation work, 19 reservoirs that did not meet the hydrogeological criteria defined for MGB have been excluded (Kleczkowski 1990; Witczak et. al. 2010; Skrzypczyk 2015). The only reservoir that has not been documented so far is the Paleogene-Neogene MGB No. 215 Warsaw Sub-trough covering an area of $51,000 \mathrm{~km}^{2}$ (Fig. 1). In order to unify the layout of hydrogeological documentations for all MGWBs, a methodological guidance document detailing integrity of cartographic presentations, databases and numerical modeling for all documentations was published.

In the period 2000-2008, based on the documentation work in Poland, protective zones were designated for 78 MGBs. The methodology for determining MGB protection zones has been standardized for all hydrogeological documentation works (Herbich et. al. 2009). The determinations were based on hydrogeological premises that take into account both the time of vertical flow through the vadose zone and the layer of the reservoir overburden, as well as the 25-year time from lateral inflow of water in the aquifer to the reservoir boundaries. The protection zone of MGB includes the supply area if the vertical flow through the vadose zone is less than 25 years. The principles for determining the MGB protection zones were established in the form of four protection types depending on the flow time needed for water infiltration from the ground surface to a saturated zone (characterized by the vulnerability of the aquifer to pollution) (Kleczkowski 1990; Witczak et. al. 2010; Krogulec 2013):

- Highly vulnerable time: below 5 years (high risk),

- Vulnerable time: 5-25 years (medium risk),

- Moderately vulnerable time: 25-50 years (low risk),

- Slightly vulnerable time: over 50 years (very low risk).

The total area of the groundwater reservoirs and the proposed protection zones documented in 2009-2016 is $87,419.7 \mathrm{~km}^{2}$. Their summary area is $84,050.6 \mathrm{~km}^{2}$, which results from the fact that the reservoirs may partly overlap because they encompass different aquifer formations, some of which are located within the same area. These MGB surfaces constitute $26.9 \%$ of the territory of Poland. Protected zones cover $48,540.09 \mathrm{~km}^{2}$, that is, $15.5 \%$ of Poland's area (https://www.pgi.gov.pl/en/psh/zadania-psh/8862-groundwate r-resources-in-poland.html). Areas of the highly vulnerable time below 5 years (high risk) do not exceed $10-30 \%$ of the Poland area and include recharge areas that are threatened by degradation.

The obligation to produce hydrogeological documentation in connection with establishing a protection zone for a groundwater reservoir is currently regulated, among others, by Geological and Mining Law Act (Geological and Mining Law 2017). The advisory body for the Minister of the Environment to approve such documentation is the Commission for Hydrogeological Documentation. The work of the Commission for Hydrogeological Documentation is regulated by the Ordinance of the Minister of the Environment as of July 17, 


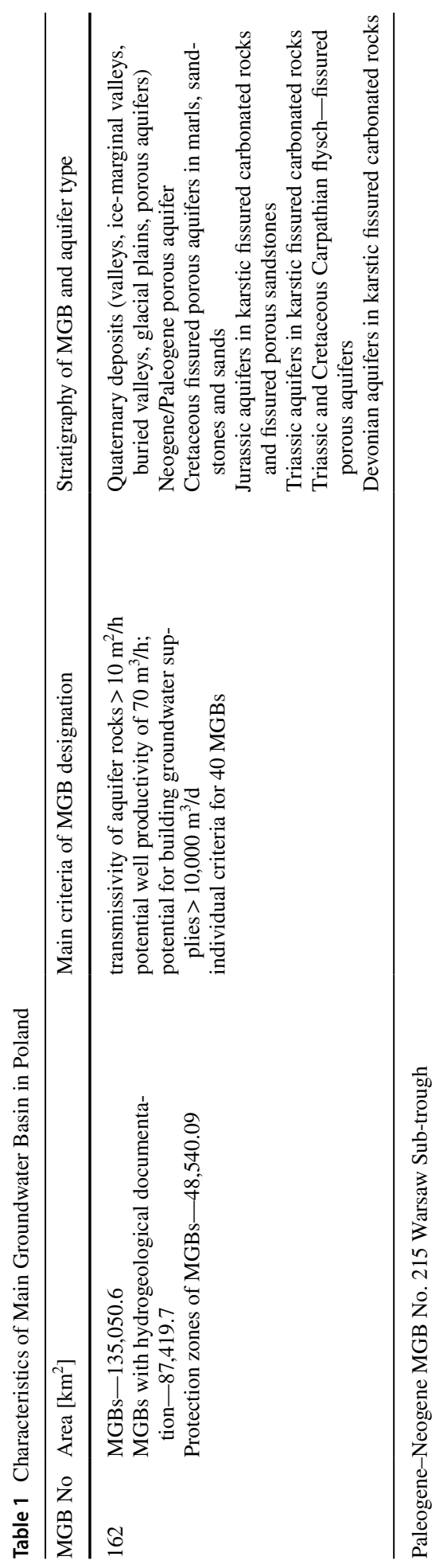




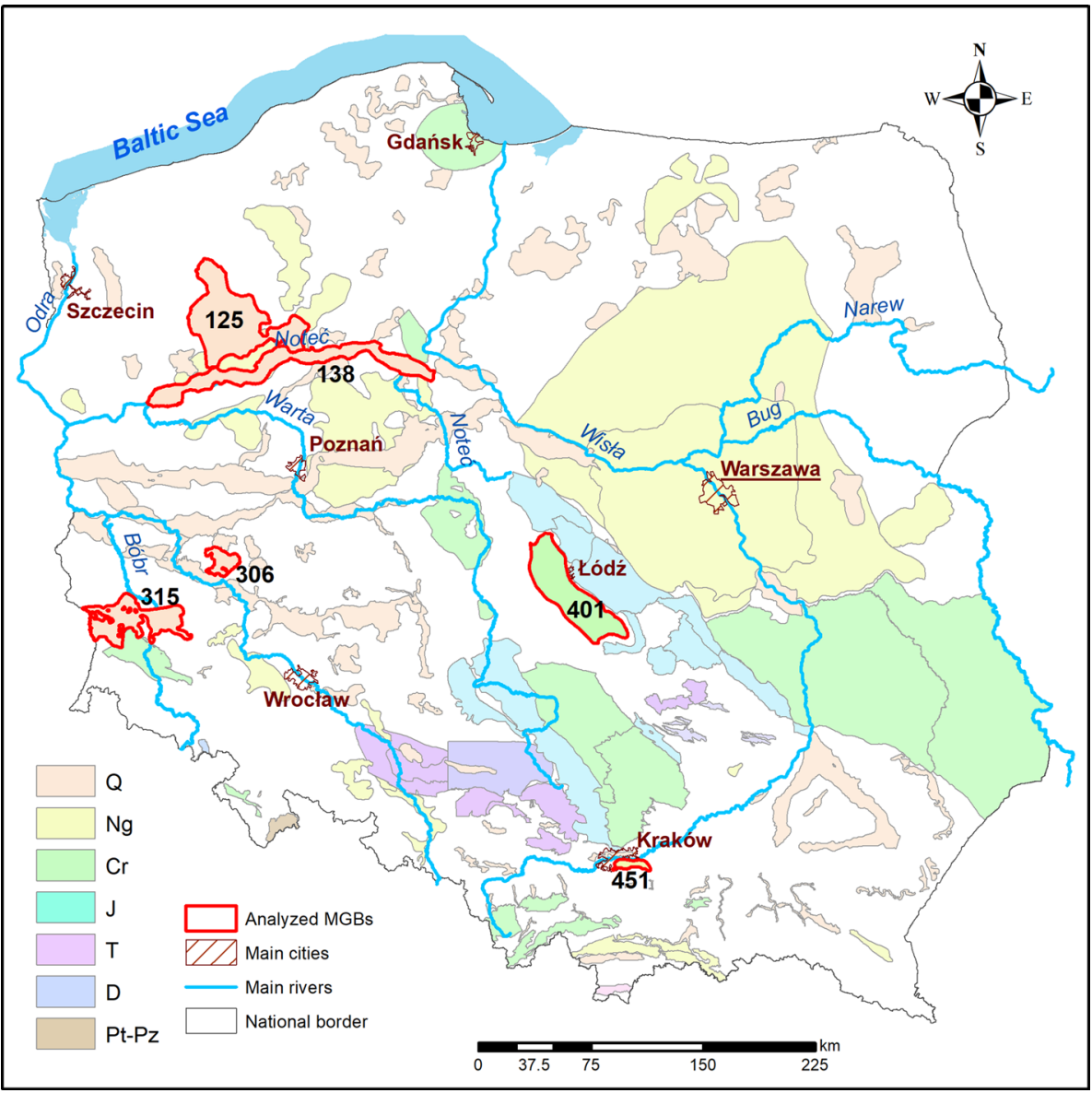

Fig. 1 Location of analyzed MGBs on the background of other MGBs in Poland

2015, on the establishment of the Commission for Hydrogeological Documentation (Regulation of the Minister of the Environment in Poland 2016).

\section{Groundwater protection in Poland in light of existing legal regulations}

Delimitation of the boundaries of MGBs and the rules for their protection are an important part of groundwater protection issues. These rules take into account previous experiences and current common legal provisions, and the methodology refers to the principles set out in the "Guidance on Groundwater in Drinking Protected Areas", which is part of the European Commission's program "Common Implementation Strategy for WFD (2000/60/EC)" (Directive 2006/118/EC).

According to Article 120 of the Act of July 20, 2017, on the Water Law (Water Act 2017), in order to ensure the appropriate quality of water abstracted for consumption and for supplying industrial plants that require high-quality water and also to protect water 
resources, it is allowed to establish protection zones of inland water reservoirs. These zones are subject to prohibitions, orders and restrictions on land or water use to protect groundwater or surface water resources against degradation. Therefore, hydrogeological documentation presents hydrogeological premises determined by groundwater vulnerability to pollution (Witczak et. al. 2010; Krogulec et. al. 2019). The whole protection zone requires approval in spatial development plans. These zones are established by the Regional Governor (Voivode), under local regulations, at the request of the National Polish Waters.

\section{Possible social consequences of setting up an MGB protection zone}

Detailed hydrogeological studies, which are the basis for determining MGB protection zones, define the area that is subject to restrictions on land use to protect groundwater. The results of designating the protection zone apply to the financial field related to land-use restrictions and, as a consequence, also to possible development and economic planning. The consequences of introducing protection zone of groundwater in MGB by defining individual prohibitions and orders an analysis of socioeconomic effects. The consequences boil down to direct consequences related to the limitation on land use and indirect ones related to the planned activities, for example, mining and construction operations, in order to minimize the conflict between economic activity and the overriding interest of water protection in MGBs.

Designation of an MGB protection zone limits, to a certain extent, the freedom to perform certain activities in relation with one's own property. Prohibitions on land use are valid for the time of documentation, while in the case of developing technologies that limit the negative effects of environmental impact, developing land management and urban spatial planning, as well as other events, they may be an obstacle. The establishment of prohibition or order, in connection with the designation of a protected zone, limits the rights to use land or real estate. In the case of planned new business activity that could potentially affect the groundwater quality, it is necessary to exclude a part of the area from protection, which means re-documenting and a new decision-making procedure.

\section{Possible cost consequences of setting up an MGB protection zone}

The economic analysis leads to the conclusion that financial costs can be temporary and individual, for example, by limiting land use, but the benefits can be long term and global. The initial analysis on establishing selected protection zones in Poland is effective sensu Kaldor-Hicks (Cooter et. al. 2016), that is, the benefits outweigh the costs regardless of the entities concerned.

The Development of cost assessment methodology is the key interest of the authors allowed for the effective analysis of this element for a particular reservoir and looks as follows. Calculations that aimed at estimating financial costs resulting from the introduction of prohibitions and restrictions on land use or water use in the proposed protection area were made for selected MGBs. In the first stage of the workflow, hydrogeological documentations were prepared, in which the extents of MGB protection areas were determined based on the analysis of hydrogeological conditions. In the second stage, the financial costs were estimated by specialists in various fields: a hydrogeologist, an assets appraiser, a lawyer, an urban planner, and a specialist in agriculture and agronomy. The estimation of costs 
consisted of delimitation of the protection area into aggregated spatial units, to which the same existing and planned development can be assigned. A legal analysis of prohibitions and restrictions that may limit the possibilities of investing and using real estate by current owners was carried out. Next, the degree of limitation of the use value of particular land and real estate was determined, and material use values were assigned to each form of limitation. In order to assess the costs correctly, the risk of claims was also assessed. As a result, potential costs per $1 \mathrm{~km}^{2}$ of surface area (referred to as unit costs) have been attributed to each homogeneous area or point object, presented for individual prohibitions and restrictions, as well as the probability of their occurrence and the type of claim. The calculations have been made for a period of two years from the assumed day of formal establishment of the MGB protection area (established by the regional Governor (Voivode)). After this time, the claims expire and the entity obliged to pay compensation may fulfill them on the basis of the fulfillment of natural obligation, but no legal coercion may be applied to it. Thus, the actual costs, however not greater than estimated, will result from the awareness and mobilization of persons having the right to make claims (Sowińska et al. 2015).

The key issue was to present and compare results in different hydrostructural conditions and types of MGB management to be able to relate these results to different circumstances in other countries. Cost estimation was made in the form of a multidimensional matrix that take into account the results obtained in earlier stages of work, and appropriate scheme of analysis is presented in Fig. 2.

The calculations made for six-selected MGBs show considerable differences in the amount of costs associated with establishing their protection areas. They vary from $€ 138,000$ per 2 years (MGB No. 306) to €21.1 million/2 years (MGB No. 401) (Table 2). Estimates were made in the Polish currency-in the paper, they are converted into Euro taking into account the average exchange rate of December 5, $2019($ PLN4.28 $=€ 1)$.

The amount of costs has a crucial impact predominantly on land use within the designated protection area, and then on its size (Gurwin et al., 2017a, b). Establishing protection areas is most expensive in urban areas, while it is cheapest in forest terrains. In order to better illustrate the costs of establishing MGB protection areas, unit costs have been calculated per $1 \mathrm{~km}^{2}$ of their surface area. Values in the range of $€ 120$ to $208,000 / 2$ years $/ 1 \mathrm{~km}^{2}$ (Table 2) were obtained. The highest value was obtained for MGB No. 451, whose protection area is characterized by high urbanization, and the lowest value was obtained for MGB No. 315, with a poorly urbanized and heavily forested protection area (Fig. 3).

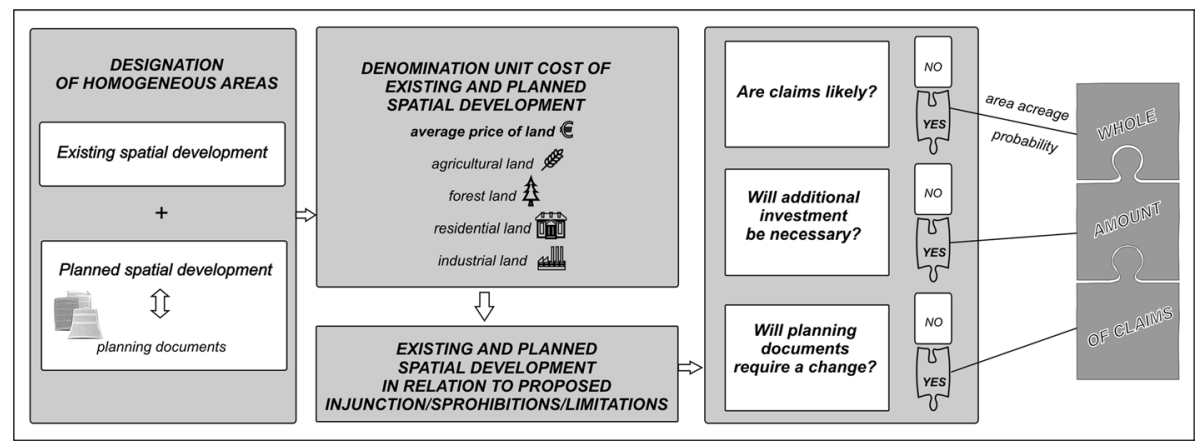

Fig. 2 Scheme of estimation of costs associated with the establishment of protection areas of MGB (after Gurwin et al., 2017a) 


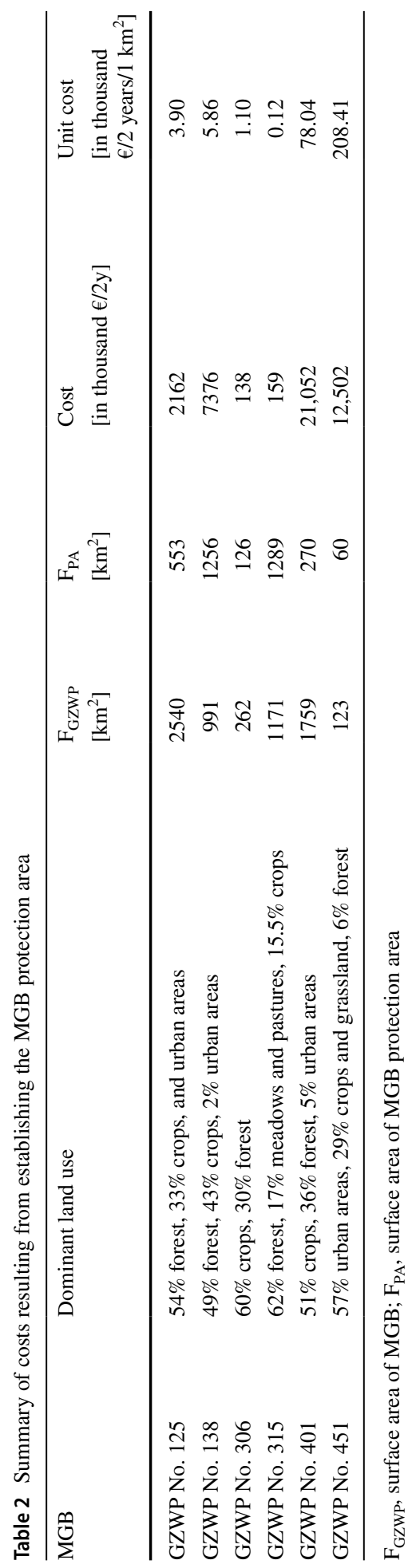


The costs are usually generated by $2-4$ prohibitions on land use in the protection area; the others have a much smaller or even marginal significance. They may be different for each analyzed case, depending on land use in the protection area. The analyses have shown that the costs are highly influenced by the prohibition on the introduction of sewage into the ground and surface waters in all MGB protection areas. In addition, in urban areas, the amount of costs will be determined by the prohibition on locating new industrial facilities without using groundwater -quality protection systems, and the prohibition on locating landfills of municipal, hazardous and other liquid and solid waste. In agricultural and forested areas, these are the prohibitions on location and extension of farms, use of plant protection measures, and agricultural utilization of sewage, and the order to limit the use of fertilizers and plant conditioners, etc. (Table 3). It should be noted that the above-mentioned costs are generated not by the prohibition themselves, but by the resulting restrictions on the use of land owned by private individuals, business entities or state institutions.

\section{Summary and conclusions}

The idea of defining major groundwater basins in Poland as the most productive groundwater systems has preceded the achievements of other EU Member States. MGBs are reservoir-containing strategic groundwater resources meeting specific quantitative and qualitative criteria. The protection zone of MGB includes the supply area if the vertical flow through the vadose zone is less than 25 years. Major groundwater basins were to be documented in Poland and in different hydrogeological structures. The hydrogeological documentation stage of the protection areas has been completed. The total area of the MGBs is $163441 \mathrm{~km}^{2}$, the area of the documented basins in $2009-2016$ is $87,419.7 \mathrm{~km}^{2}$, and protected zones cover $48,540.09 \mathrm{~km}^{2}$.

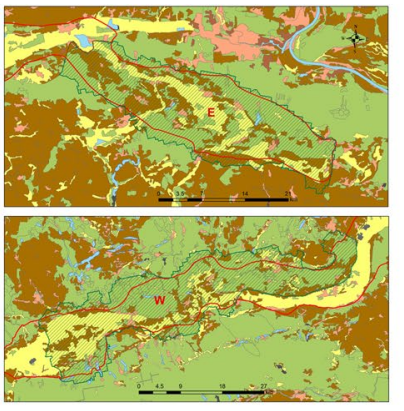

MGB 138

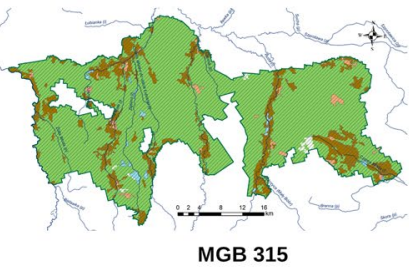

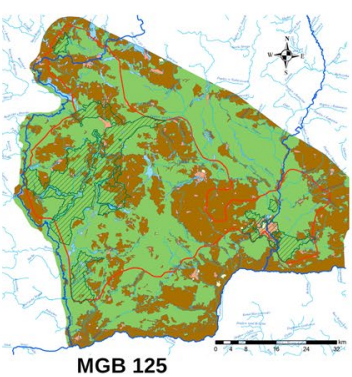
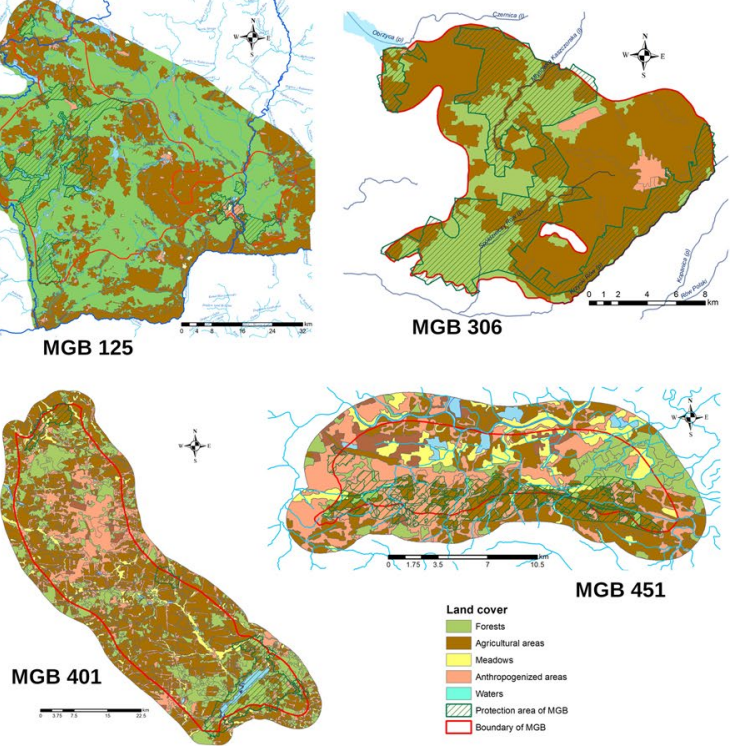

Fig. 3 Land cover maps of analyzed MGBs 
Table 3 Summary of selected prohibitions and restrictions determining the amount of costs resulting from the establishment of MGB protection area

\begin{tabular}{|c|c|c|c|c|c|c|c|c|c|c|c|c|}
\hline \multirow[t]{2}{*}{ MGB } & \multicolumn{12}{|c|}{ Share in total costs of selected prohibitions and restrictions [\%] } \\
\hline & A & B & $\mathrm{C}$ & $\mathrm{D}$ & $\mathrm{E}$ & $\mathrm{F}$ & G & $\mathrm{H}$ & I & $\mathrm{J}$ & $\mathrm{K}$ & $\mathrm{L}$ \\
\hline GZWP No. 125 & 46.4 & & 3.3 & & & 10.9 & 13.1 & 10.2 & 1.5 & & & 2.1 \\
\hline GZWP No. 138 & 42.7 & 25.7 & 7.6 & 2.6 & 0.4 & 5.4 & 4.0 & 0.7 & 0.4 & 10.4 & & \\
\hline GZWP No. 306 & 9.5 & 28.7 & 20.1 & 9.3 & & 6.8 & 3.5 & & & & 9.2 & 12.8 \\
\hline GZWP No. 315 & 28.6 & 8.9 & 7.2 & 3.4 & 5.7 & 6.8 & & & 8.7 & & 19.8 & 9.7 \\
\hline GZWP No. 401 & 46.3 & & 2.2 & & & & & 9.4 & 34.4 & & & 1.1 \\
\hline GZWP No. 451 & 30.2 & 0.3 & 0.3 & & & 0.3 & 3.4 & 29.8 & 32.7 & & 1.6 & 0.3 \\
\hline
\end{tabular}

A: prohibition on the introduction of sewage into the ground and into surface waters, with the exception of rain and snowmelt water and rinsing waters; B: prohibition on locating and expanding farms; C: prohibition on agricultural use of sewage, and the order to limit the use of fertilizers and plant conditioners; D: prohibition on locating cemeteries and burying animal corpses; E: prohibition on locating liquid fuel stations; F: prohibition on using plant protection products other than approved for use; G: prohibition on building and developing public roads and using chemicals; $\mathrm{H}$ : prohibition on locating new industrial facilities without the use of impermeable ground, watertight rain and snowmelt water systems; I: prohibition on locating landfills of municipal, hazardous, nonhazardous and neutral liquid and solid waste; J: prohibition on building pipelines transporting hazardous substances; K: prohibition on locating household sewage treatment plants with drainage systems; L: prohibition on storing waste and residues from agricultural production without tight isolation from the ground

The study showed that the analysis of the costs of establishing protection areas must be an interdisciplinary action undertaken by a group of specialists from various fields being integrated in a uniform operating scheme. A new look at this problem is the assessment by the same method of several groundwater basins with diverse hydrostructural conditions, different ages, different sizes, levels of groundwater abstraction and various development. There was demonstrated a clear relationship between the development of the protected area and the amount of costs. The consequences of introducing a protection zone of groundwater in MGB boil down to direct consequences related to the limitation on land use, and indirect ones related to the planned activities, for example, mining and building operations. Establishment of rules including prohibitions and orders with respect to land use, land management, in connection with the designation of a protected zone, limits the rights to use land or real estate. Legal frameworks for groundwater have to form an integral part of context-based groundwater governance, which must be adapted to each country's financial, technological, political and law systems, and prevailing practices. The experience gained so far that has enabled the determination of MGB protection zones in Poland indicates the need for a flexible approach because of the cost-benefit relationship. The socioeconomic consequences related to limited land use and development conditions in protection zones are taken into account. To date, no MGB protective zone has been formally and in accordance with the law established in Poland.

Establishing a protection area will involve increased financial outlays for previous and future activities. It will limit the use of the property and cause claims. The economic consequences of establishing a protected area may include the following:

- limitation or cancellation of existing use rights,

- buying back or exchanging real estate for another with a right (possibility) for using an analogous one/obtaining productivity analogous to the lost one, 
- one-off compensation for the reduction in real estate value,

- one-off compensation for the need to implement an investment leading to compliance with new requirements,

- one-off compensation-a claim made for increased operating costs,

- one-off compensation-a claim made for a decrease in productivity/profitability of real estate.

Establishing protection will help protect groundwater by stopping environmental degradation and maintaining (improving) the groundwater quality. In the long run, this will reduce the financial outlays for the treatment of groundwater intended for consumption, improve tourism assets and, indirectly, will have a positive impact on the health of the inhabitants. The main beneficiary of establishing a protection area will be all inhabitants of the area and users of groundwater. The greatest benefits will be obtained directly by economic entities selling water intended for consumption to the population and the industrial plants requiring high-quality water and indirectly by the State Treasury.

The costs of establishing groundwater protection, estimated from $€ 120$ to $€$ $208,000 / 2$ years $/ 1 \mathrm{~km}^{2}$, indicate their large disproportion, resulting primarily from the development of the area that is intended to be protected. The algorithms of cost estimation developed by the authors should be treated as a universal proposition. Cost estimates for basins with such diverse hydrogeological and land development conditions give a chance for a preliminary rough cost estimate by comparing similar structures in any country.

When establishing protection areas, it is worth remembering that the costs incurred for the prevention of environmental pollution, including groundwater, are statistically three to four times lower than the costs of reclamation of an already-polluted environment. In addition, in the context of forecasted climate changes, groundwater will become superior.

Funding This work was supported by the University of Warsaw and the University of Wroclaw.

Open Access This article is licensed under a Creative Commons Attribution 4.0 International License, which permits use, sharing, adaptation, distribution and reproduction in any medium or format, as long as you give appropriate credit to the original author(s) and the source, provide a link to the Creative Commons licence, and indicate if changes were made. The images or other third party material in this article are included in the article's Creative Commons licence, unless indicated otherwise in a credit line to the material. If material is not included in the article's Creative Commons licence and your intended use is not permitted by statutory regulation or exceeds the permitted use, you will need to obtain permission directly from the copyright holder. To view a copy of this licence, visit http://creativecommons.org/licenses/by/4.0/.

\section{References}

Bussard, T., Tacher, L., Parriaux, A., \& Maître, V. (2006). Methodology for delineating groundwater protection areas against persistent contaminants. Quarterly Journal of Engineering Geology \& Hydrogeology, 39(1), 97-109.

Cooter, R., Ulen, T., (2016). Law and economics. Berkeley law books, Retrieved 31 June 2019 from http://schol arship.law.berkeley.edu/books/2.

Council Directive 91/676/EEC of 12 December 1991 concerning the protection of waters against pollution caused by nitrates from agricultural sources [1991] 31991L0676.

Council Directive 91/692/EEC of 23 December 1991 standardizing and rationalizing reports on the implementation of certain Directives relating to the environment [1991] 31991L0692; Council Directive 92/43/EEC of 21 May 1992 on the conservation of natural habitats and of wild fauna and flora [1992] 31992L0043; Directive 2012/18/EU of the European Parliament and of the Council of 4 July 2012 on the control of major-accident hazards involving dangerous substances, amending and subsequently repealing; Council Directive 96/82/EC Text with EEA relevance[2012] 32012L0018. 
Directive 2000/60/EC of the European Parliament and of the Council of 23 October 2000 establishing a framework for Community action in the field of water policy [2000] OJ L327/1 (WFD).

Directive 2006/118/EC of The European Parliament and of the Council of 12 December 2006 on the protection of groundwater against pollution and deterioration [2006] OJ L 372.

Environmental Protection Law. Journal of Laws (Dziennik Ustaw) No. 129 of 2006, (EPL) Pos. 902. (Consolidated version) LEX-FAOC060001. (In Polish).

Garcıa Garcıa, A., \& Martınez Navarrete, C. (2005). Protection of groundwater intended for human consumption in the water framework directive: Strategies and regulations applied in some European countries. Pol Geol Inst Spec Pap, 18, 28-32.

Geological and mining law. Journal of Laws (Dziennik Ustaw) of 2017, Act of June 9, 2011, item 2126 (PGG). (In Polish).

Gurwin, J., Pajewski, K., Sowińska, K., \& Wąsik, M. (2017). Metodyka szacowania kosztów ustanawiania obszaru ochronnego GZWP na przykładzie zbiornika nr 138 Pradolina Toruń-Eberswalde (methodology of estimating costs of establishing MGB protection areas based on MGB No. 138 Pradolina Toruń-Eberswalde). Przeglad Geologiczny, 65(11/1), 1055-1061.

Gurwin, J., Sowińska, K., \& Wąsik, M. (2017). Problematyka szacowania kosztów ustanawiania obszarów ochronnych wybranych GZWP w utworach czwartorzędowych w regionie środkowej Odry (the problem of estimating costs of establishing protection areas in selected MGBs in the quaternary aquifers of the middle Odra region). Przeglad Geol., 65(11/1), 1062-1068. ((In Polish)).

Herbich, P., Kapuściński, J., Nowicki, K., Prażak, J., Skrzypczyk, L., (2009). Methodology of delineating protection areas of major groundwater basins for planning and water management in river catchment areas (in Polish). PGI, Warszawa, p.70. (In Polish). Retrieved from 10 july 2019 from https://www.pgi.gov.pl/en/ psh/zadania-psh/8862-groundwater-resources-in-poland.html.

Jiménez-Madrid, A., Carrasco-Cantos, F., \& Martínez-Navarrete, C. (2012). Protection of groundwater intended for human consumption: A proposed methodology for defining safeguard zones. Environmental Earth Science, 65, 2391-2406. https://doi.org/10.1007/s12665-011-1494-x.

Jiménez-Madrid, A., Carrasco, F., \& Martínez, C., (2016) Activities permitted cartography: The integration of groundwater protection into land-use planning. Environmental Earth Science, 75, 1372. https://doi. org/10.1007/s12665-016-6197-x.

Jiménez-Madrid, A., Gómez, S., \& Gémar, G., Martínez. C., (2018). A proposed methodology for assessing the economic needs of safeguard zones protecting groundwater intended for human consumption within the context of the European water framework directive. International Environmental Agreements, 18, $723-742$.

Kleczkowski, A., (1984) Groundwater protection, Wydanie Geology, Warszawa, p. 328. (In Polish).

Kleczkowski, A. (1990). The map of the critical protection areas (CPA) of the major groundwater basin (MGWB) in Poland, scale 1:500000. Kraków: AGH. ((In Polish)).

Krogulec, E. (2013). Intrinsic and specific vulnerability of groundwater in a river valley: Assessment, verification and analysis of uncertainty. Journal of Earth Science and Climatic Change. https://doi. org/10.4172/2157-7617.1000159/1-12.

Krogulec, E., Zabłocki, S., \& Zadrożna, D. (2019). Variability of intrinsic groundwater vulnerability to pollution in river valley due to groundwater depth and recharge changes. Applied Sciences, 9(6), 1133. https:// doi.org/10.3390/app9061133.

Mechlem, K. (2016). Groundwater governance: The role of legal frameworks at the local and national levelestablished practice and emerging trends. Water, 8, 347. https://doi.org/10.3390/w8080347.

Regulation of the Council of Ministers of June 27, 2006 on the course of boundaries of river basins and water regions (Journal of Laws of 2006 No. 126, item 878 and of 2010 No. 130 item 874). (In Polish).

Regulation of the Minister of the Environment in Poland, Journal of Laws (Dziennik Ustaw) of 18 October 2016 r, item 2033. (In Polish).

Samuelson P, Nordhaus W (1999) Ekonomia, Wyd. Naukowe PWN, Poznań, p. 728. (In Polish).

Skrzypczyk, L. (2015). Map of preliminary valorisation of the major groundwater basins as cartographic representation of documentation of groundwater reservoirs, with establishing direction for further work and research. Przeglad Geologiczny, 53(10/2), 921-925.

Stiglitz J (2004) Globalizacja, Wyd. Naukowe PWN, Warszawa, p. 233. (In Polish).

Sowińska K, Wąsik M, Gurwin J, Serafin R, Tatomir T, Gołąb R, Jańczak R, Calik-Jończak A (2015) The methods of preliminary estimation of costs of establishing protection areas of Major Groundwater Basins in the area of the Warta Water Region. ECOGEM. Mędłów, p. 728. (In Polish).

The Spatial Planning and Development. Journal of Laws (Dziennik Ustaw) No. 80, Pos. 717. Act of 27 March 2003 (UPZP) (Consolidated version 2018). (In Polish).

Ulman-Bortnowska M (1995) Dokumentowanie zbiorników wód podziemnych i ustalanie zasad ochrony obszarów ich zasilania (wskazania), MOŚZNiL, Warszawa, p. 46. (In Polish). 
Water Act. 2017 (PW). Journal of Law (Dziennik Ustaw) No. 1566, Act 20 July 2017. (In Polish).

Witczak, S., Szczepański, A., Mikołajków, J., \& Skrzypczyk, L. (2010). Protection of groundwater quality and quantity of strategic groundwater resources of the major groundwater basins. Przeglad Geologiczny, $58(9 / 1), 754-761$.

Publisher's Note Springer Nature remains neutral with regard to jurisdictional claims in published maps and institutional affiliations. 